\title{
The effect of a single injection of mepivacaine hydrochloride on spermatogenesis in the rat*
}

\author{
M. A. Banhawy, R. M. A. Rashed, K. Bowler $\dagger$ and M. J. Stacey \\ Department of Zoology, Ain Shams University, Cairo, Egypt and † Department of Zoology, \\ University of Durham, Durham DHI $3 L E, U . K$.
}

The purpose of this communication is to report that an intraperitoneal injection of a local anaesthetic, mepivacaine ((1-methyl-DL-piperidine-2-carboxylic acid)-2,6-dimethylanilide hydrochloride), caused deleterious changes to the seminiferous epithelium of the rat testis. The effect of this reagent on spermatogenesis was studied because it is reported that it affects blood flow (Aberg \& Wahlström, 1972 ) and it is well known that spermatogenesis is very sensitive to reduced blood flow (Cross \& Silver, 1962).

Twenty 120-150 g male rats (CFHB strain) were each given a single intraperitoneal injection of mepivacaine hydrochloride(Bofors, Nobel-Pharma, Sweden). Ten rats received $0 \cdot 1 \mathrm{ml}$ and the others $0.25 \mathrm{ml}$ of a $4 \%$ solution ( $40 \mathrm{mg}$ mepivacaine $+95 \mathrm{mg}$ glucose per $\mathrm{ml}$ water). Two rats from each dose group were killed after 6 or $12 \mathrm{~h}, 1,2$ or 10 days and their testes were removed for histological examination. Control rats (12) were given a single intraperitoneal injection of $0.5 \mathrm{ml}$ glucose solution $(95 \mathrm{mg}$ glucose per $\mathrm{ml}$ ), and were killed 2 days later. Each testis was cut through the equator and fixed in either Bouin's fluid or in Zenker-formol. The tissue was embedded in paraffin wax and sectioned at $5 \mu \mathrm{m}$. The sections were stained according to the PAS technique used by Leblond \& Clermont (1952).

Examination of the sections showed that some histological damage had occurred in all animals after the single injection of mepivacaine, but no damage was evident in the control animals. In the experimental animals not all tubules in a section were damaged but those that were could be separated into two types. (1) 'Partially' damaged tubules. It was difficult to determine with certainty the stage of the cycle, as defined by Leblond \& Clermont (1952), in these tubules but they contained some normal germ cells. (2) 'Severely' damaged tubules. In these only a ring of Sertoli cells and/or degenerating germ cells remained. A similar classification of damaged tubules was used by Bowler (1972) in studies on the effect of heat on spermatogenesis in rats.

'Severe' or 'partial' damage occurred in $30-50 \%$ of the tubules in a cross-section of tissue from 18 of the 20 treated rats. Only 'partially' damaged tubules were observed in tissue from the other two rats, which were killed 12 and $24 \mathrm{~h}$ after the dose of $10 \mathrm{mg}$ mepivacaine (PI. 1, Figs 2 and 3): most of the tubules appeared normal, in others the epithelium was reduced. In such tubules it was only the oldest generation of spermatids that were missing, but in some the primary spermatocyte layer was also affected. Apart from these two animals, in which the damage was slight, it was not possible to distinguish between the rats receiving the two dose levels. It is concluded that the variation in response is likely to result from a difference in susceptibility rather than rate of absorption.

Damage was evident as early as $6 \mathrm{~h}$ after the injection in both treatment groups. Damaged tubules were characterized by the presence of pyknotic nuclei and evidence of cell shedding from the epithelium. This cell loss continued and some tubules contained cell debris in the lumen up to $24 \mathrm{~h}$ after the injection (see Pl. 1, Fig. 3). The epithelium of damaged tubules always had a vacuolated appearance (Plate 1). Testes removed after 2 days were similar to each other in appearance: many tubules were normal, some were abnormal in that the oldest spermatid layer was absent (see Pl. 1, Fig. 4), and some were 'partially' or 'severely' damaged. In all four animals killed after 10 days, many normal tubules were present in the testis and all stages of the cycle, as defined by Leblond \& Clermont (1952), were represented. In some tubules resurgence of spermatogenesis was at an early stage, presumably because the spermatogonia had not been affected by the mepivacaine injection, but about $10 \%$ of tubules were more seriously affected and no spermatogenic activity was evident (Pl. 1, Figs 5 and 6).

* Reprint requests to Dr K. Bowler, Department of Zoology, University of Durham, Durham, U.K. 
The damage occurring after mepivacaine injection is clearly different from that after scrotal heating. The most sensitive cells to heating are the primary spermatocytes (stages IX and XIV) and step 1 spermatids, while older spermatids are more resistant (Steinberger \& Dixon, 1959; Collins \& Lacy, 1969; Chowdhury \& Steinberger, 1970; Parvinen, 1973). In the present study primary spermatocytes were lost from some tubules (Pl. 1, Fig. 2), but there was no evidence for the loss of step 1 spermatids. It was instead the older generation of spermatids that was most frequently lost, particularly in tubules at stages III-V of the cycle. In this respect the damage also differs from that following ischaemia (Steinberger \& Tjioe, 1969).

The injurious effect of mepivacaine on rat testis is, at least superficially, similar to that reported for 5-hydroxytryptamine (Boccabella, Salgado \& Alger, 1962; O’Steen, 1963; Kormano, Karhunen \& Kahanpaa, 1968) and histamine (O'Steen, 1963). These authors found that (i) there was considerable variation in individual susceptibility, and (ii) only a proportion of tubules were damaged and of these some were markedly damaged with the epithelium reduced to a ring of Sertoli cells only. Unfortunately these studies were not sufficiently detailed to allow more precise comparison with the present findings.

Boccabella et al. (1962) concluded that 5-hydroxytryptamine injury to the testis resulted from reduced blood flow, because the simultaneous administration of vasodilator prevented the testis damage. The results of Kormano et al. (1968) support this hypothesis as they found no evidence for 5-hydroxytryptamine penetration into testicular tissue and they also concluded that temporary ischaemia was the most likely cause of the injury. O'Steen (1963) considered that such agents as 5-hydroxytryptamine and histamine would be too rapidly metabolized to have a long enough effect on blood flow through the testes to cause injury.

Cross \& Silver (1962) and Waites \& Setchell (1966) have drawn attention to the extreme sensitivity of spermatogenesis to reduced blood flow. Mepivacaine is reported to have vasoconstrictor effects (Aberg \& Wahlström, 1972), and it may therefore cause sufficient ischaemia to impair spermatogenesis. However, although the effects of temporary ischaemia, as reported by Oettlé \& Harrison (1952), apparently resemble those caused by mepivacaine injection, the more detailed account of the response to ischaemia by Steinberger \& Tijoe (1969) differs significantly from the effects of mepivacaine described here. It is therefore difficult to decide, at this stage in the study, the mechanism whereby mepivacaine injures spermatogenesis.

\section{EXPLANATION OF PLATE 1}

Transverse sections of testes of rats after an intraperitoneal injection of $4 \%$ mepivacaine hydrochloride in glucose solution.

Fig. 1. Testis $12 \mathrm{~h}$ after receiving $4 \mathrm{mg}$ mepivacaine. Almost all tubules were damaged. Note the presence of 'partially' and 'severely' damaged tubules, 'vacuolation' and the absence of 'maturation-phase' spermatids. $\times 100$.

Fig. 2. Testis $12 \mathrm{~h}$ after receiving $10 \mathrm{mg}$ mepivacaine. In this testis the damage was slight and no 'severely' damaged tubules were found. In some tubules primary spermatocytes have been lost as well as 'maturationphase' spermatids. Cell debris is present in the tubule lumen. $\times 100$.

Fig. 3. Testis $24 \mathrm{~h}$ after receiving $10 \mathrm{mg}$ mepivacaine. The damage was slight and no 'severely' damaged tubules were found. 'Vacuolation' can be seen in the epithelium in some tubules. The most obvious damage is the absence of 'maturation-phase' spermatids from some tubules. $\times 100$.

Fig. 4. Testis $48 \mathrm{~h}$ after receiving $10 \mathrm{mg}$ mepivacaine. 'Partially' and 'severely' damaged tubules are evident and all tubules show signs of damage, particularly lack of 'maturation-phase' spermatids. 'Vacuolation' of the epithelium is also evident. $\times 100$.

Fig. 5. Testis 10 days after injection of $4 \mathrm{mg}$ mepivacaine. 'Severely' damaged and normal tubules are present. $\times 100$.

Fig. 6. Testis 10 days after treatment with $10 \mathrm{mg}$ mepivacaine, showing a 'severely' damaged tubule with only Sertoli cells present. $\times 250$. 


\section{PLATE 1}
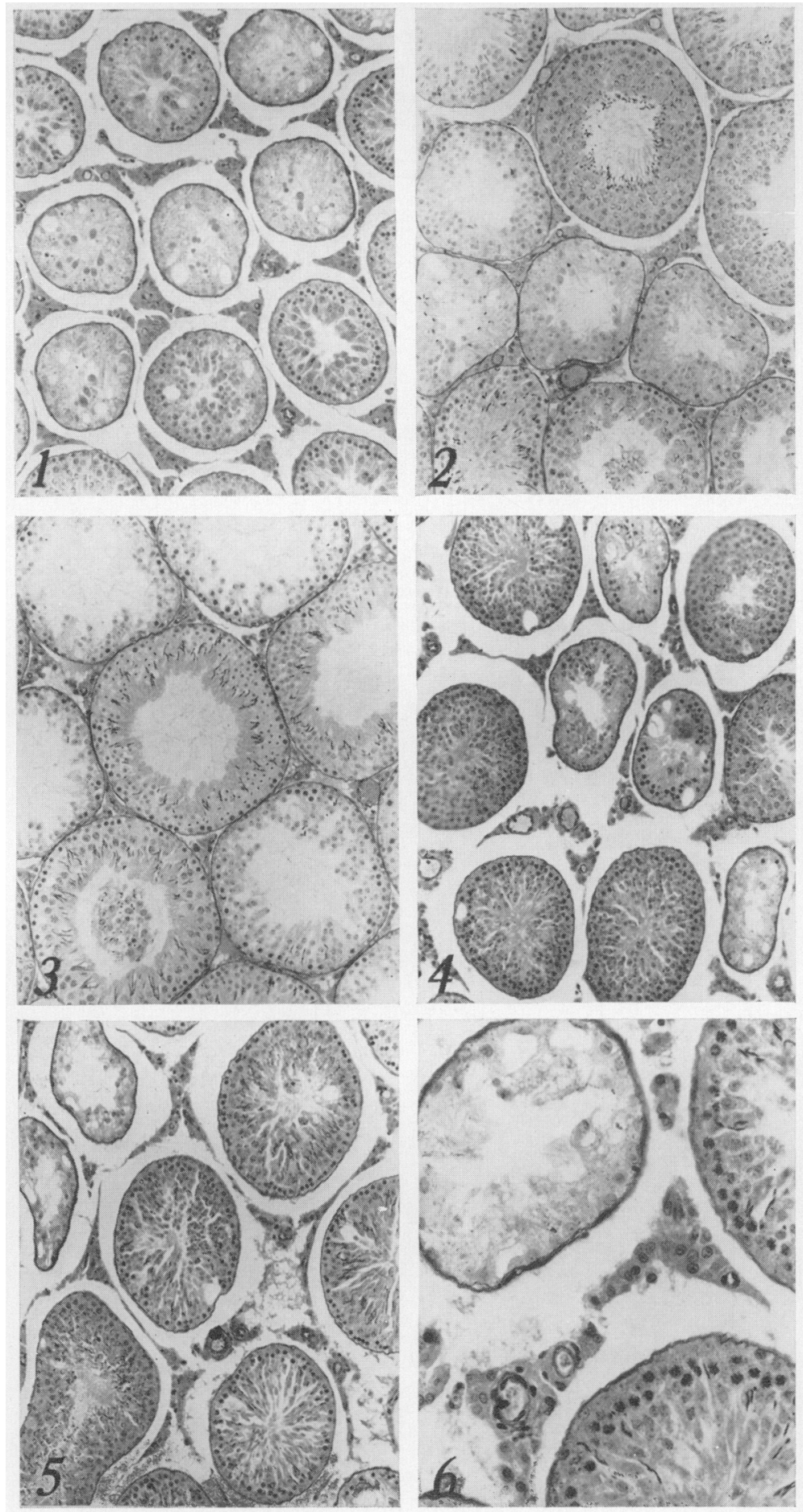


\section{References}

AbERG, G. \& WAHLSTröM, B. (1972) Mechanical and electrophysiological effects of some local anaesthetic agents and their isomers on the rat portal vein. Acta pharm. toxicol.31, 255-266.

Boccabella, A.V., Salgado, E.D. \& Alger, E.A. (1962) Testicular function and histology following serotonin administration. Endocrinology 71, 827-837.

BOWLER, K. (1972) The effect of repeated applications of heat on spermatogenesis in the rat: a histological study.J. Reprod. Fert. 28, 325-333.

Chowdhury, A.K. \& Steinberger, E. (1970) Early changes in the germinal epithelium of rat testes following exposure to heat. J. Reprod. Fert. 22, 205-212.

Collins, P. \& LACY, D. (1969) Studies on the structure and function of the mammalian testis. II. Cytological and histochemical observations on the testis of rat after a single exposure to heat applied for different lengths of time. Proc. $R$. Soc. B 172, 17-38.

Cross, B.A. \& Silver, I.A. (1962) Neurovascular control of oxygen tension in the testis and epididymis. $J$. Reprod. Fert. 3, 377-395.

Kormano, M., Karhunen, P. \& KahanpaA, K. (1968) Effect of long-term 5-hydroxytryptamine treatment on the rat testis. Annls Med. exp. Biol. Fenn. 45, $474-478$.
Leblond, C.P. \& Clermont, Y. (1952) Definition of the stages of the cycle of the seminiferous epithelium in the rat. Ann. N.Y. Acad. Sci. 55, 548-573.

OetTlé, A.G. \& Harrison, R.G. (1952) The histological changes produced in the rat testis by temporary and permanent occlusion of the testicular artery. $J$. Path. Bact. 64, 273-297.

O'STEEN, W.K. (1963) Serotonin and histamine: effects of a single injection on the mouse testis and prostate gland. Proc. Soc. exp. Biol. Med. 113, 161-163.

Parvinen, M. (1973) Observations on freshly isolated and accurately identified spermatogenic cells of the rat. Early effects of heat and short-time experimental cryptorchidism. Virchows Arch. Zell path. 13, 3847.

Steingerger, E. \& Dixon, W.J. (1959) Some observations of the effects of heat on the testicular germinal epithelium. Fert. Steril. 10, 578-595.

Steinberger, E. \& TJioe, D.Y. (1969) Spermatogenesis in rat testes after experimental ischaemia. Fert. Steril. 20, 639-649.

Wattes, G.M.H. \& Setchell, B.P. (1966) Changes in blood flow and vascular permeability of the testis, epididymis and accessory reproductive organs of the rat after administration of cadmium chloride. $J$. Endocr. 34, 329-342.

Received 28 March 1977 